\title{
The Wealth Effect of New Product Introductions on Industry Rivals*
}

\section{Introduction}

New product introductions create opportunities for differentiation and competitive advantage and can have a positive impact on the announcing firm's value (Kleinschmidt and Cooper 1991). Using financial market-based analysis, previous studies (such as Woolridge 1988; Chaney, Devinney, and Winer 1991; Kelm, Narayanan, and Pinches 1995; Lane and Jacobson 1995; and Chen and Ho 1997) documented positive announcement effects of new product introductions on the market value of the announcing firms. These studies from the literature in finance, marketing, strategic management, and industrial organization also related the announcement effects to the characteristics of the announcing firms, their industries, or the products themselves.

Although the results on the wealth effect of new product introductions on the announcing firms are insightful, they do not tell us how the values of other firms in the industry are affected by the

* We thank Kasim Ali, Dosuong Choi, David Ding, Robert H. Gertner, Frank C. Jen, Cheng-few Lee, an anonymous referee, as well as seminar participants at the 1999 FMA Annual Meeting and the 1999 PACAP/FMA Conference for helpful comments and suggestions. Ho acknowledges funding from Nanyang Technological University.

(Journal of Business, 2005, vol. 78, no. 03)

(C) 2005 by The University of Chicago. All rights reserved. 0021-9398/2005/7803-0008\$10.00
We find that, on average, rivals of firms announcing new products experience a significantly negative wealth effect. We also show that rivals in technologically based industries experience the most significantly unfavorable effect. Rivals' share price response is more unfavorable when the wealth effect on the announcers is larger and when frequent announcers introduce new products. Smaller rivals and those with better investment opportunities also are more adversely affected. Further, highly leveraged rivals, especially those in concentrated industries, experience a greater wealth loss. However, we find that rivals' wealth effects are more favorable when the products introduced are very new. 
announcements. ${ }^{1}$ Mahajan, Sharma, and Buzzell (1993) suggest that the effects of new product announcements on the competitors depend on the interaction of the following two effects: the market expansion effect and the market substitution effect. Product innovation activities could have positive spillover effects on other firms in the industry because new products could expand the market boundaries or create entirely new markets and, hence, benefit the incumbents. For example, Mahajan et al. (1993) use the case of Eastman Kodak Company and Polaroid Corporation in the instant camera market to show that the market expansion effect can be significant. The introduction of the instant cameras by Kodak expanded the market by $37 \%$, which also benefited its rival, Polaroid. This market expansion effect implies that industry rivals should experience a positive wealth impact when the announcing firms introduce their new products.

On the other hand, if the new products invade the incumbents' existing market, they might suffer a wealth loss due to competition. For example, the Wall Street Journal (June 17, 1996) reported that the share price of In Focus Systems Inc. lost 34\% on June 14, 1996, on worries about the impact of a new product unveiled by Sony Electronics Inc. Sony Electronics introduced a series of liquid-crystal-display projectors for computers, which were what In Focus Systems made. This effect of market substitution suggests that industry rivals should suffer a negative wealth impact when the announcers introduce their new products. ${ }^{2}$

Previous evidence on the impact of new product announcements on industry rivals is scarce, and the results are mixed. Using a sample of new product introductions in the computer industry, Ashok (1994) shows that industry rivals of the announcers generally suffer a negative wealth effect. In contrast, Lee (1995) finds a positive announcementperiod wealth effect on the rivals for a sample of new product introductions in the brewing, long distance communication, and personal computer industries. However, he documents that, in the case of imitation by followers, rivals suffer a negative wealth impact.

Ashok (1994) and Lee (1995) provide limited insight into the wealth impact on industry rivals at the time of new product introductions

1. Recent studies document that announcements by a firm could contain signals about firms in the corresponding industry. For example, see Foster (1981); Eckbo (1983); Baginski (1987); Han, Wild, and Ramesh (1989); Slovin, Sushka, and Bendeck (1991); Lang and Stulz (1992); Slovin, Sushka, and Polonchek (1992); Szewczyk (1992); Firth (1996); and Eckel, Eckel, and Singal (1997). However, other studies, such as Aharony and Swary (1983) and Hertzel (1991), show that such announcements could convey no information about the industry.

2. Klemperer and Padilla (1997) suggest that industry rivals can also suffer from an indirect business-stealing effect of a new product introduction. They argue that a firm that offers an extra product could capture not only consumers' business for that product but also for other products of rival firms. This effect contrasts with the standard business-stealing effect (see Mankiw and Whinston 1986) that arises when a rival introduces a product that is a substitute for the products already being offered in the market. 
because their studies focus on only a single industry or a very few selected industries. In our study, we examine new product announcements in 60 industries based on the four-digit Standard Industrial Classification (SIC) code. With a comprehensive list of industries, we can examine potentially significant differences in the intraindustry impact of new product introductions across different industries.

In addition, previous studies provide limited understanding of the cross-sectional variation of the wealth impact of new product introductions on rival firms. For example, Lee (1995) examines the impact of only entry order on the wealth effect of the rivals. In this study, we examine a broad list of potentially important factors that could explain the cross-sectional variation of the wealth effect of new product announcements on industry rivals. These factors, which are drawn from the literature in finance, marketing, management, and industrial organization, include industry variables, such as the degree of industry competition and the industry type (whether a high-technology industry or otherwise); firm variables, such as rivals' firm size, investment opportunities, free cash flow, R\&D intensity, and leverage; and product variables, such as product newness, single- or multiple-product announcement, and entry timing. In addition, we also include the announcement frequency and the announcement-period abnormal returns of the announcing firms in our cross-sectional analysis.

For a sample of 863 announcements of new product introductions from 1987 to 1995, we find that, consistent with previous studies, the average announcement-period abnormal return for the announcing firms is significantly positive. We also find that, on average, rival firms experience a small but significantly negative share price response. The results suggest that, for the sample as a whole, the market substitution effect dominates the market expansion effect. Our findings show that a substantial portion of the market value gains of innovating firms represents "business stealing" from industry rivals. We also find a significantly negative relation between the announcement returns of the announcers and those of the rivals. This result is consistent with the notion that, if the announcement is "big news" for the announcer, the wealth effect on industry rivals should be larger (more negative) because of the greater element of surprise (see Hertzel 1991; Firth 1996; and others).

We further classify the rivals' share price response by industry and find that rivals in technologically based industries (such as pharmaceuticals preparations, computer and office equipment, electronic and other electric equipment, radio and TV communication equipment, and semiconductors) experience the most-significantly unfavorable share price response. Chaney, Devinney, and Winer (1991) suggest that firms in these industries require new innovations to stay alive. Therefore, in these industries, rivals that lag behind in product innovation are likely to 
suffer a greater loss of competitive advantage and experience a more negative wealth effect.

We find that industry rivals' negative share price response is more pronounced when their firm size is smaller. Thus, smaller firms, which need product innovations to survive in the market (Chaney et al. 1991), are more vulnerable to competitors' challenges. Further, information asymmetry is more severe for small firms (Atiase 1985; Chaney et al. 1991; and others), which suggests that the negative impact on firm value induced by public announcements of new product introductions are more pronounced for small rival firms.

Next, we show that rival firms with better investment opportunities experience a more unfavorable wealth effect. Firms with better investment opportunities are expected to have worthwhile investments and to make better investment decisions (Lang, Stulz, and Walkling 1989, 1991 and others). Our results suggest that the market is disappointed with these firms that did not perform up to the market's expectation. Also, investors might cast doubts on these firms' ability to compete and their effectiveness in seizing their growth opportunities. Hence, investors' assessment of the wealth effect of new product introductions on those rival firms that have better investment opportunities is more pessimistic than that on other rival firms that have limited or poor investment opportunities.

We further find that, on average, rival firms with higher financial leverage experience a more adverse wealth effect than those with lower leverage. This finding supports that leveraged firms are more vulnerable in product market competition than unleveraged firms (Myers 1977; Stulz 1990; Phillips 1995; Lang, Ofek, and Stulz 1996; Kovenock and Phillips 1997; and others). We also examine the interaction effect of rivals' debt level and industry concentration. Our results show that the negative relation between rivals' debt ratio and their share price response is significant only for those rival firms in concentrated industries. In contrast, we find that debt ratio has no significant impact on the wealth effect of rivals in less-concentrated industries. Our results support that the vulnerability of leveraged firms in product market competition is more severe in concentrated industries (Lang and Stulz 1992; Opler and Titman 1994; and others).

We show that rivals' share price response is significantly positively related to product newness. Mahajan et al. (1993) suggest that the market expansion effect of a new product introduction is more likely to happen early in the process of market evolution. Therefore, when the products introduced are original, there is a greater likelihood of an accelerated market growth, which would benefit industry rivals. On the other hand, when the products introduced are simply updates of existing products, it is less likely for the market to experience an accelerated growth; hence, industry rivals would not benefit much from any potential market expansion. 
Our results also show that new product announcements made by frequent announcers indicate a more unfavorable wealth effect on industry rivals. This finding is consistent with the notion that frequent announcers are able to capitalize on follow-on investment projects and generate future investment opportunities, which can erode the competitive position of the rival firms (Chen et al. 2002).

The remainder of the paper proceeds as follows. Section II reviews the literature and develops the hypotheses on the potentially important determinants that could explain the cross-sectional variation of the wealth effect of new product introductions on industry rivals. Section III describes the sample selection and methodology. Section IV reports the results on the stock price response for the announcing firms and the industry rivals and the results of the cross-sectional analysis. Section V concludes the paper.

\section{The Determinants of the Wealth Effect of New Product Introductions On Rivals}

In this section, we discuss the potentially important variables that could explain the cross-sectional variation of the wealth impact of new product introductions on industry rivals. We identify these variables from different strands of research in the areas of finance, marketing, management, and industrial organization. We discuss our hypotheses under four headings: the degree of surprise (or alternatively, the extent of anticipation of the new product announcements), industry characteristics, rivals' firm characteristics, and product announcement type.

\section{A. Degree of Surprise}

Announcer's announcement-period abnormal return. The extent of the announcement effects of new product introductions on rivals is influenced by the extent to which the announcement is anticipated (Chaney et al 1991). If an announcement is "big news," there should be a large effect on the announcer and a large effect on the rivals (Hertzel 1991; Firth 1996; and others). Thus, conditioning on the wealth effect on the announcers is essential in our understanding of the cross-sectional variation of the wealth effect on the rivals. ${ }^{3}$ A positive relation between the abnormal returns of the announcers and those of the rivals indicates that, in aggregate, the market expansion effect dominates the market substitution effect. On the other hand, a significantly negative relation indicates that, on the whole, the market substitution effect dominates the market expansion effect.

3. Eckbo (1983) and Stillman (1983) show that conditioning on the announcement effect on the announcers is also important in analyzing the effect of merger announcements on industry rivals. 
Announcement Frequency. Chaney et al. (1991) find that the number of products introduced by the announcers during the sample period negatively influences the excess return of the announcing firms. Their results suggest that the degree of surprise is smaller when the new product announcements are made by firms that have a history of making frequent product announcements; hence, the intraindustry effect of these announcements should be less significant.

\section{B. Industry Characteristics}

Degree of industry competition. Hendricks and Singhal (1997) argue that, in a highly competitive industry, customers are more likely to have the option of buying a competing product from a number of firms. Further, when competition is tougher, the capacity to introduce new products faster and on time is likely to be an important source of differentiation and competitive advantage. Thus, those rivals lagging behind in introducing new products in a highly competitive industry are more likely to experience lost sales, lower profits, and a loss of competitive advantage. Therefore, we expect that, when announcers introduce new products, rivals in more-competitive industries experience a more-unfavorable wealth impact than those in less-competitive industries.

High-technology industry. Chaney et al. (1991) suggest that firms that are technologically based require new product innovations to stay alive. They also argue that the value of an innovation is higher for firms in more technologically based industries. They show that the value of a new product announcement, as measured by the announcement-period abnormal return, is the greatest for the most technologically based industries, such as computers, chemicals, petroleum, pharmaceuticals, printing, and electrical equipment and appliances. Their findings suggest that laggard rival firms in technologically based industries are likely to lose more competitive advantage and be affected more adversely than those in low-technology industries when new products are introduced by the announcers. Therefore, we hypothesize that the wealth impact of new product introductions on rivals in high-tech industries is more unfavorable than that on rivals in low-tech industries.

\section{Rivals' Firm Characteristics}

Firm size. Scherer and Ross (1990) argue that large firms are generally more established and diversified; hence, they are better able to withstand competitors' moves. Large firms may be slow in innovation pace, but when they are threatened by new product development in the industry, the market expects them to respond to the challenge. In addition, large firms generally have a wider range of products; hence, they should be less adversely affected by any single product introduction by their industry competitors (Hendricks and Singhal 1997). In contrast, small firms need product innovation to survive in the market 
(Chaney et al. 1991). They are more vulnerable to competitors' challenges. Therefore, we expect smaller rival firms to suffer a more unfavorable competitive effect caused by new product introductions than larger rival firms.

An argument based on information asymmetry also suggests that the wealth effect is more severe for small firms than for large firms. Atiase (1985) and Chaney et al. (1991) argue that information production and dissemination is a positive function of firm size. Therefore, the expected change in firm value induced by public announcements of new product introductions are more pronounced for small rival firms. ${ }^{4}$

Investment opportunities. Rival firms with better investment opportunities are likely to have worthwhile projects and generally be perceived by the market as firms having better investment decisions (Lang et al. 1989, 1991; and others). If they do not perform up to the market's expectation, such as lagging behind in the activities of new product development, the market might be disappointed. Investors might also start to cast doubts on these firms' strategic plans and their ability to compete. Further, rivals that have better investment opportunities are likely to have more growth options. The value of these growth options could be impaired by the introduction of new products by the announcers; hence, the market value of those rival firms with better investment opportunities could be adversely affected. In contrast, the market perception of those rival firms with limited or poor investment opportunities could be relatively unaffected by new product announcements in the industry. Therefore, we expect that, at the announcement of new product introductions, rival firms with better investment opportunities suffer a more-unfavorable wealth effect than rival firms with poorer investment opportunities. ${ }^{5}$

Free cash flow. The availability of internal funds has an impact on corporate investment (Fazzari, Hubbard, and Petersen 1988; Hoshi, Kashyap, and Scharfstein 1991; and others). High-free-cash-flow firms have better ability to invest (Lang and Stulz 1992) and more flexibility to respond to changes in market conditions (Bolton and Scharfstein 1990). If they lag behind in new product development, the market might be disappointed with their ability to compete with their competitors. Market participants could even perceive that the laggard high-free-cashflow firms are diverting their efforts to negative net present value (NPV) projects (Jensen 1986). Therefore, we expect rivals with high free cash

4. Slovin, Sushka, and Benedeck (1991) find supporting evidence that the valuation effect on industry rivals is more pronounced for small firms than for large firms in the case of goingprivate announcements.

5. Akhigbe and Madura (1996) examine the role of investment opportunities in explaining the intraindustry stock price effect of voluntary liquidation announcements. They also find a negative relation between rivals' share price response and their investment opportunities. 
flow to have a more unfavorable wealth effect than rivals with low free cash flow.

$R \& D$ intensity. Kelm et al. (1995) argue that firms with intensive $\mathrm{R} \& \mathrm{D}$ are expected to have greater technology capability and opportunities for product innovation. When firms announce product innovation, they are expected to seize some technological opportunities and appropriate most of the benefits associated with the innovation. Industry rivals therefore are at a competitive disadvantage (Mauri and Michaels 1998). In addition, significantly new technology enables announcers to seek patent protection. In this case, industry rivals could waste all incurred efforts in similar technology opportunities. Therefore, when the announcers introduce new products, rivals with intensive R\&D are expected to experience poorer share price response.

Leverage. Jensen (1986) suggests that debt can reduce free cash flow that may otherwise be allocated to inefficient investment. However, a firm's debt overhang could be large enough to prevent it from raising funds to finance positive NPV projects (Myers 1977; Stulz 1990; Phillips 1995; Lang et al. 1996; Kovenock and Phillips 1997; and others). Recent research suggests that a firm's capital structure can also play an important role in explaining product market competition. For example, Bolton and Scharfstein's (1990) "long purse" (or "deep pockets") hypothesis suggests that cash-rich firms can drive their financially constrained competitors out of business. They suggest that, while external financing disciplines management, it makes the firm vulnerable in its product markets. Maurer's (1999) model also suggests that an unleveraged rival can take predatory action to drive a leveraged firm out of the market. ${ }^{6}$

Several empirical studies show that leverage increases have an impact on product market competition. For example, Chevalier (1995) finds that the announcement of a leveraged buyout (LBO) increases the expected future profits of a firm's product-market rivals, and the presence of LBO firms encourages local entry and expansion by rivals. Phillips (1995) finds that firms that increase their financial leverage can lose market share or fail to gain market share when smaller rivals exit the industry. Zingales (1998) shows that, after the deregulation of the trucking industry, highly leveraged carriers are less likely to survive. The author suggests that the underinvestment problem caused by the high debt might have forced these firms out of the market.

These studies suggest that a firm's debt level could limit its ability to respond to the competitive challenges posed by new product introductions by the announcers. Therefore, we hypothesize that firms with

6. Earlier theoretical papers on the interaction between capital structure and product market behavior include Brander and Lewis (1986); Gertner, Gibbons, and Scharfstein (1988); Maksimovic (1988); and Poitevin (1989). Kovenock and Phillips (1995) examine how to reconcile theory and evidence in this area. 
higher debt level should suffer a more-unfavorable wealth effect as a result of the new product announcements.

Several studies suggest that the impact of leverage on product market competition might depend on the degree of industry concentration. For example, Lang and Stulz (1992) show that, although, on average, bankruptcy announcements decrease the value of bankrupt firm's competitors, rival firms in highly concentrated industries with low leverage actually benefit from the difficulties of the bankrupt firm. Opler and Titman (1994) find that leveraged firms in concentrated industries experience relatively high losses in industry recessions. They suggest that industry concentration could be a proxy for the gains associated with removing a weakened competitor. When a leveraged firm in a concentrated industry is in trouble, the fewer competitors in the industry that are bigger players gain more by forcing this leveraged firm out of business. Hence, highly leveraged rival firms in concentrated industries should be more adversely affected by the introduction of new products by the announcers. ${ }^{7}$

\section{Product Announcement Type}

Product newness. Original products are likely to be more successful (Booz, Allen, and Hamilton 1982). They are expected to create better opportunities for product differentiation and strengthen the announcing firms' competitive advantage (Kleinschmidt and Cooper 1991). They also create better potential for the announcers to generate a long-term stream of cash flow (Chaney et al. 1991), resulting in a better firm performance (Meyer and Roberts 1986; Firth and Narayanan 1996).

As for the impact on rival firms, original products introduced by announcers might cause the rivals to lose more competitive advantage than updates of existing products. Rivals might lack similar technology or knowledge to imitate the products and respond appropriately in time. Further, the announcing firms can obtain patents and build up substantial entry barriers, which can adversely affect rival firms.

In contrast, Mahajan et al. (1993) suggest that the market expansion effect of a new product introduction is more likely to happen early in the process of market evolution. Thus, when the products introduced are original, the likelihood of accelerated market growth is greater. This market expansion effect benefits the rivals. The accelerated growth of the instant camera market, highlighted in our introduction, is an illustration of the extent of the positive effect on industry rivals that can be generated by the introduction of an original product. Thus, when announcers introduce original products, the wealth effect on industry

7. Kovenock and Phillips (1997) also show the importance of interacting debt variables with market concentration variables when analyzing corporate investment decisions. They find that the effect of high leverage on investment and plant closing is significant when the industry is highly concentrated. In particular, they find that, following its recapitalization, a firm in an industry with high concentration is more likely to close plants and less likely to invest. 
rivals could be favorable. On the other hand, when the products introduced are updates of existing products, the likelihood of an accelerated market growth is lower, and hence, the wealth effect on industry rivals could be less favorable.

Single- or multiple-product announcement. Chaney et al. (1991) report that firms that announce the introduction of multiple products experience more wealth gains than those that announce single products. Other things being equal, firms introducing more products are likely to have more R\&D expenditures, patented inventions, and skilled labor (Acs and Audretsch 1988). They are also more competitive in the product market and seize more market share, especially when the total market is growing very slowly (Hendricks and Singhal 1997). These studies suggest that multiple-product announcers could appropriate much of the benefits associated with product innovation, and their rivals could therefore experience a greater degree of competitive disadvantage. Hence, we hypothesize that, when the announcers introduce multiple products, industry rivals experience poorer share price response.

Entry timing. Previous studies suggest that firms that are among the first to enter an industry enjoy the so-called first-mover's advantage. ${ }^{8}$ For example, Jovanovic and MacDonald (1994) studied the life cycle of the U.S. automobile tire industry and found that firms that scale up early enjoy higher rents during the early phases of the industry life cycle and, hence, have higher market values. Bernardo and Chowdhry (2002) also show that, among the firms that expand, those that expand early have higher valuations.

Lee (1995) argues that first movers are at a competitive advantage over the competitors because of the entry barriers the first movers can erect, which can deter responses by rivals and enhance the first movers' ability to earn excess profits. The losses or lost opportunities for the competitors due to the first mover's monopolist advantages should have a negative impact on rivals. When followers imitate new product introductions, they (i.e., the imitators) also share some of the monopolist profits. Thus, when imitative responses take place, rival firms could also be adversely affected. However, the adverse effect on the rivals at the time of imitation should be smaller than that at the time of product introductions by first movers, since the announcing firms have more monopolistic advantages in the latter case than in the former case. Thus, industry rivals could be affected more adversely by the first movers' announcements than by the followers' announcements.

8. Mueller (1997) identifies four categories of first mover advantage related to demand and supply factors and links these concepts to that of path dependence. However, it is not always advantageous to move first. One disadvantage is that, by moving first, the firm gives up some flexibility, which can be valuable (Trigeorgis 1996; Saloner, Shepard, and Podolny 2001; and others). 
On the other hand, Mahajan et al. (1993) argue that the market expansion effect of a new product introduction is more likely to happen early in the sequence of successive entries into a market. Thus, the rivals of a first mover could benefit more from any market expansion effect than rivals of a second mover.

\section{Sample Selection and Methodology}

In this section, we first provide a description of our sample. Then, we describe how we measure announcement-period abnormal return and proxy variables for the cross-sectional analysis.

\section{A. Sample}

We collect our sample of initial announcements of new product introductions by firms listed on either the New York Stock Exchange (NYSE) or the American Stock Exchange (AMEX) from Dow Jones News Retrieval Service database, which provides news-service articles and selected stories from the Wall Street Journal (WSJ), Dow Jones News Wire $(D J N W)$, and Barron's. ${ }^{9}$ We select the words and phrases and their synonyms commonly used to describe new product introductions as keys for a database search routine. Examples are introduce, new product, unveil, launch, received approval, to market, test market, begin selling, along with other pertinent words and phrases. We include both new products and product updates, as in Chaney et al. (1991). We also identify the information on the firms, products, and other information (such as marketing information) from the news contents. The sample period is from January 1987 to December 1995.

To avoid any confounding events that could distort the measurement of the valuation effects on the announcing firms and the intraindustry effects, we exclude those announcements by firms that have other announcements 5 days before or after the initial announcement date. We also exclude the announcements if there is no rival firm in the announcing firm's industry, which we define by the four-digit SIC code in Compustat (as in Lang and Stulz 1992 and others). ${ }^{10}$ Finally, we exclude the announcing firms or their rivals if no data on them is available from the Center for Research in Securities Prices (CRSP) returns files and the Compustat files.

9. As mentioned by Chan, Martin, and Kensinger (1990), this data source is more comprehensive than the Wall Street Journal Index because specific news announcements that appear in $D J N W$ or in the $W S J$ are not always reflected in the index. However, as mentioned by Chaney et al. (1991), the sample from this data source may not represent all new products; the sample here can be described as a sample of "significant" announcements.

10. As indicated by Guenther and Rosman (1994) and Kahle and Walkling (1996), the CRSP SIC codes are not very representative of the industries in which the firms actually operate, which can lead to less precise inferences. Compustat SIC codes appear to be more reliable. 
Our final sample comprises 863 new product announcements by 158 firms in 60 industries. ${ }^{11}$ Table 1 provides the sample distribution by year of announcement and industry. Consistent with Chaney et al. (1991), the announcements come mainly from four industries: chemicals and pharmaceuticals (2800, 2820-1, 2834-6, 2840, 2844), computers (3570-2, 3575-9), electrical equipment and appliances (3600, $3621,3630,3640,3651,3661,3663,3674,3690)$, and instruments and photographic equipment $(3825,3841-2,3844-5,3851,3861)$. The four broad categories constitute about $76 \%$ of the total sample. Firms in the computer and office equipment industry (3570) have the highest frequency of introducing new products; on average, each firm in this industry has made about 28 announcements in the 9-year sample period.

\section{B. Measuring Announcement-Period Abnormal Returns}

We employ standard event-study methods to examine stock price responses to announcements of new product introductions. We define day 0 as the initial announcement date. We calculate the abnormal return as the difference between the actual return and an expected return generated by the market model. We use the value-weighted CRSP index as a proxy for market returns and estimate the parameters of the market model using the data over a period from 200 to 60 days before the announcement date. We calculate abnormal returns for the announcing firms and for the industry rivals, and conduct significance tests using the $Z$-statistic, as described in Dodd and Warner (1983).

\section{Measuring Proxy Variables for the Cross-Sectional Analysis}

We collect data on the industry and the rivals' firm characteristics from the Compustat files. We measure the degree of industry competition by the Herfindahl index (HI), which equals the sum of the squared fraction ofindustry sales by all firms in the industry for the fiscal year prior to the announcement (as in Lang and Stulz 1992 and Hendricks and Singhal 1997). ${ }^{12}$ While this index is a measure of concentration, it has been widely used as a proxy for competitiveness because the degree of concentration and the degree of competition are generally inversely related. A lower value of Herfindahl index means a higher degree of competition. We create a dummy variable (HIGH TECH) that equals 1 if the rival firms are in a high-technology industry and zero otherwise. Industries are classified as high- and low-technology industries according to the classification in Chan, Marton, and Kensinger (1990).

11. In addition, 549 firms are included as industry rivals.

12. The same results hold if the Herfindahl ratio is computed using all firms in the industry excluding the announcer. We obtain similar results if, instead of using a continuous variable for the Herfindahl index, we use a dummy variable that equals 1 if an industry's Herfindahl index is greater than the sample median and zero otherwise (as in Hendricks and Singhal 1997). The mean (median) measure of Herfindahl index is $0.11(0.07)$. 
TABLE 1 Distribution of New Product Introductions by Year and Industry

\begin{tabular}{|c|c|c|c|c|}
\hline & $\begin{array}{c}\text { Number of } \\
\text { Announcements }\end{array}$ & $\begin{array}{l}\text { Percent of } \\
\text { Sample }\end{array}$ & $\begin{array}{l}\text { Number of } \\
\text { Firms }\end{array}$ & $\begin{array}{c}\text { Announcements } \\
\text { per Firm }\end{array}$ \\
\hline \multicolumn{5}{|c|}{ A. Sample by Year } \\
\hline 1987 & 86 & 9.96 & & \\
\hline 1988 & 91 & 10.54 & & \\
\hline 1989 & 107 & 12.40 & & \\
\hline 1990 & 138 & 16.00 & & \\
\hline 1991 & 77 & 8.92 & & \\
\hline 1992 & 57 & 6.61 & & \\
\hline 1993 & 85 & 9.85 & & \\
\hline 1994 & 77 & 8.92 & & \\
\hline 1995 & 145 & 16.80 & & \\
\hline Total & 863 & 100.00 & & \\
\hline
\end{tabular}

\section{B. Sample by Industry}

Food and kindred products (2000)

Preserved fruits and vegetables (2030)

Grain mill products (2040)

Sugar and confectionery products (2060)

Beverages (2080)

Paper mills (2621)

Misc. converted paper products (2670)

Newspapers (2711)

Chemicals and allied products (2800)

Plastics materials and synthetics (2820)

Plastics materials and resins (2821)

Pharmaceuticals preparations (2834)

Diagnostic substances (2835)

Biological products not

Soap, cleaners and toilet goods (2840)

Toilet preparations (2844)

Petroleum refining (2911)

Glass/glassware (3220)

Misc. nonmetallic mineral

Farm machinery and equipment (3523) 
TABLE 1

\begin{tabular}{|c|c|c|c|c|}
\hline & $\begin{array}{c}\text { Number of } \\
\text { Announcements }\end{array}$ & $\begin{array}{l}\text { Percent of } \\
\text { Sample }\end{array}$ & $\begin{array}{l}\text { Number of } \\
\text { Firms }\end{array}$ & $\begin{array}{c}\text { Announcements } \\
\text { per Firm }\end{array}$ \\
\hline $\begin{array}{l}\text { Metalworking } \\
\text { machinery (3540) }\end{array}$ & 2 & .23 & 1 & 2.0 \\
\hline Special industry & & & & \\
\hline $\begin{array}{l}\text { machinery (3559) } \\
\text { General industry }\end{array}$ & 1 & .12 & 1 & 1.0 \\
\hline machinery (3569) & 1 & .12 & 1 & 1.0 \\
\hline $\begin{array}{l}\text { Computer and office } \\
\text { equipment (3570) }\end{array}$ & 199 & 23.06 & 7 & 28.4 \\
\hline $\begin{array}{l}\text { Electronic computers } \\
\quad(3571)\end{array}$ & 69 & 8.00 & 9 & 7.7 \\
\hline $\begin{array}{l}\text { Computer storage } \\
\text { devices }(3572)\end{array}$ & 14 & 1.62 & 3 & 4.7 \\
\hline $\begin{array}{l}\text { Computer terminals } \\
\text { (3575) }\end{array}$ & 1 & .12 & 1 & 1.0 \\
\hline $\begin{array}{l}\text { Computers-others } \\
\text { (3576) }\end{array}$ & 4 & .46 & 1 & 4.0 \\
\hline $\begin{array}{l}\text { Computer peripherals } \\
\text { (3577) }\end{array}$ & 5 & .58 & 3 & 1.7 \\
\hline $\begin{array}{l}\text { Calculating/accounting } \\
\text { equipment (3578) }\end{array}$ & 6 & .70 & 2 & 3.0 \\
\hline Office machines (3579) & 2 & .23 & 1 & 2.0 \\
\hline $\begin{array}{l}\text { Electronic/other electric } \\
\text { equipment }(3600)\end{array}$ & 30 & 3.48 & 3 & 10.0 \\
\hline $\begin{array}{l}\text { Motors and generators } \\
\text { (3621) }\end{array}$ & 1 & .12 & 1 & 1.0 \\
\hline $\begin{array}{l}\text { Household appliances } \\
\text { (3630) }\end{array}$ & 1 & .12 & 1 & 1.0 \\
\hline $\begin{array}{l}\text { Electric lighting/wiring } \\
\text { equipment }(3640)\end{array}$ & 2 & .23 & 1 & 2.0 \\
\hline $\begin{array}{l}\text { Household audio/video } \\
\text { equipment }(3651)\end{array}$ & 35 & 4.06 & 3 & 11.7 \\
\hline $\begin{array}{l}\text { Telephone and telegraph } \\
\text { apparatus (3661) }\end{array}$ & 15 & 1.74 & 4 & 3.8 \\
\hline $\begin{array}{l}\text { Radio/TV communication } \\
\text { equipment (3663) }\end{array}$ & 34 & 3.94 & 4 & 8.5 \\
\hline Semiconductors (3674) & 20 & 2.32 & 6 & 3.3 \\
\hline $\begin{array}{l}\text { Misc. electrical } \\
\text { equipment/supplies } \\
(3690)\end{array}$ & 1 & .12 & 1 & 1.0 \\
\hline $\begin{array}{l}\text { Motor vehicles and } \\
\text { car bodies (3711) }\end{array}$ & 40 & 4.63 & 6 & 6.7 \\
\hline $\begin{array}{l}\text { Motor vehicle parts } \\
\text { (3714) }\end{array}$ & 3 & .35 & 2 & 1.5 \\
\hline Aircraft (3721) & 5 & .58 & 1 & 5.0 \\
\hline $\begin{array}{l}\text { Aircraft engines and } \\
\text { parts }(3724)\end{array}$ & 2 & .23 & 1 & 2.0 \\
\hline Guided missiles (3760) & 2 & .23 & 1 & 2.0 \\
\hline $\begin{array}{l}\text { Instruments and related } \\
\text { products }(3825)\end{array}$ & 6 & .70 & 3 & 2.0 \\
\hline $\begin{array}{l}\text { Surgical and medical } \\
\text { instruments (3841) }\end{array}$ & 4 & .46 & 3 & 1.3 \\
\hline $\begin{array}{l}\text { Surgical appliance and } \\
\text { supplies (3842) }\end{array}$ & 1 & .12 & 1 & 1.0 \\
\hline $\begin{array}{l}\text { X-ray apparatus and } \\
\text { tubes }(3844)\end{array}$ & 1 & .12 & 1 & 1.0 \\
\hline
\end{tabular}


TABLE 1 (Continued)

\begin{tabular}{lcccc}
\hline & $\begin{array}{c}\text { Number of } \\
\text { Announcements }\end{array}$ & $\begin{array}{c}\text { Percent of } \\
\text { Sample }\end{array}$ & $\begin{array}{c}\text { Number of } \\
\text { Firms }\end{array}$ & $\begin{array}{c}\text { Announcements } \\
\text { per Firm }\end{array}$ \\
\hline $\begin{array}{l}\text { Electromedical } \\
\text { equipment (3845) }\end{array}$ & 10 & 1.16 & 5 & 2.0 \\
$\begin{array}{l}\text { Ophthalmic goods } \\
\quad(3851)\end{array}$ & 7 & .81 & 1 & 7.0 \\
$\begin{array}{l}\text { Photographic } \\
\text { equipment/supplies }\end{array}$ & 53 & 6.14 & 2 & 26.5 \\
$\quad(3861)$ Dolls and stuffed toys & 6 & .70 & 1 & 6.0 \\
$\quad(3942)$ & 2 & .23 & 1 & 2.0 \\
$\begin{array}{l}\text { Games/toys/children's } \\
\quad \text { vehicles (3944) }\end{array}$ & 52 & 6.03 & 6 & 8.7 \\
$\begin{array}{l}\text { Telephone communication } \\
\text { not radio (4813) }\end{array}$ & 5 & .58 & 2 & 2.5 \\
$\begin{array}{l}\text { Hotels and motels (7011) } \\
\text { Motion pictures (7819) }\end{array}$ & 1 & .12 & 1 & 1.0 \\
\hline
\end{tabular}

NotE.- This table summarizes the sample distribution of new product announcements by firms listed on either the NYSE or AMEX from 1987 to 1995. We collect the sample from Dow Jones News Retrieval Service database. There are 863 announcements by 158 firms in 60 industries. The industries are based on the four-digit SIC code in Compustat.

We measure firm size (SIZE) by the logarithm of book value of total assets for the fiscal year preceding the announcement (as in Chaney et al. 1991; and others). ${ }^{13}$ We estimate investment opportunities (Q) by a simple measure of Tobin's $q$ : the ratio of the market to book value of the firm's assets, where the market value of assets equals the book value of assets minus the book value of common equity plus the market value of common equity (as in Denis 1994; Barclay and Smith 1995; Kang and Stulz 1996; Chen and Ho 1997; and Holderness, Kroszner, and Sheehan 1999). ${ }^{14}$ Our $q$ variable is the average $q$ ratio for the 3 fiscal years prior to the announcement. ${ }^{15}$ High- $q$ firms (i.e., firms with good investment opportunities) are those with a $q$ value above 1 , and low- $q$ firms (i.e., firms with poor investment opportunities) are those with a $q$ value below 1 (as in Lang et al. 1991; Howe, He, and Kao 1992; and others). ${ }^{16} \mathrm{We}$

13. The mean (median) book value of total assets for the rivals in our sample is $\$ 11,355$ $(\$ 1,989)$ millions.

14. The theoretical Tobin's $q$, defined as the ratio of the market value of a firm to the replacement costs of its assets, has been used to distinguish firms with good investment opportunities from those with poor investment opportunities (see Lang et al. 1989, 1991; and others). Because of data availability, we use this simple measure of $q$ that has been widely used in previous studies. Chung and Pruitt (1994) show that at least $96.6 \%$ of the variability of Tobin's $q$ is explained by this simple measure of $q$.

15. This follows the approach used in Lang et al. $(1989,1991)$ and Chen and Ho (1997). A 3-year average gives a better estimate of a firm's true $q$ (Lang et al. 1989). The mean (median) $q$ for the rivals is 1.97 (1.56).

16. Our results are similar if we define high- $q$ firms as those with $q$ above the sample median and low- $q$ firms as those with $q$ below the sample median (as in Howton, Howton, and Perfect 1998; and others). 
use a dummy that takes a value of 1 for high- $q$ firms and zero for low- $q$ firms (as in Lang et al. 1991; and others). ${ }^{17}$

We define free cash flow (FCF) as operating income before depreciation minus interest expense, taxes, preferred dividends, and common dividends, divided by the book value of the total assets, for the fiscal year preceding the announcement (as in Lehn and Poulsen 1989; Lang et al. 1991; and others). ${ }^{18}$ R\&D intensity (RDI) equals R\&D per dollar of sales for the fiscal year prior to the announcement (as in Deng, Lev, and Narin 1999; Chan, Lakonishok, and Sougiannis 2001; and others). ${ }^{19}$

We measure leverage (DEBT RATIO) as the book value of the total debt divided by the book value of the total assets, for the fiscal year preceding the announcement (as in Lang and Stulz 1992; and others). ${ }^{20}$ To test the interaction effect of debt level and industry concentration,

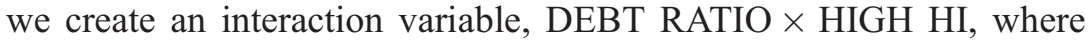
HIGH HI is a dummy variable that equals 1 when the industry Herfindahl index is greater than the sample median and zero otherwise.

We identify product announcement type, such as product newness, single- or multiple-product announcement, and entry timing, by using a structural content analysis on the news contents (as in Lee 1995; Firth and Narayanan 1996). This approach is frequently used in the study of realized strategies and managerial cognitions. We conducted a pilot study to extract the relevant key words for later characterization. We then carried out two rounds of content analysis to ensure the appropriateness of the classification. Based on this analysis of the news contents, we create three dummy variables: MULTIPLE, TIME, and NEW. MULTIPLE equals 1 for multiple-product announcements and zero for single-product announcements (as in Chaney et al. 1991). TIME equals 1 if the announcing firm is the first mover and zero otherwise (as in Lee 1995). Finally, NEW equals 1 if the product is an original product and zero if it is an update (as in Chaney et al. 1991). ${ }^{21}$

Finally, following Chaney et al. (1991), we measure the announcement frequency (FREQ) as the number of new product announcements made by an announcing firm over the sample period.

17. The motivation is that a sufficient condition for the availability of good investment opportunities is a $q$ that exceeds 1 . Furthermore, the relationship between abnormal returns and $q$ may be nonlinear. Lang et al. (1989) and Chung, Wright, and Charoenwong (1998) provide similar reasons for their preference for the dichotomous variable for investment opportunities. Our results are similar but weaker if we use a continuous variable for $q$, probably due to the nonlinear relationship between abnormal returns and $q$.

18. The mean (median) free cash flow ratio for the rivals is $7.26 \%(8.18 \%)$.

19. The mean (median) R\&D intensity for the rivals is $8.98 \%(7.20 \%)$.

20. The mean (median) debt ratio for the rivals is $20.6 \%(19.3 \%)$.

21 . We can identify 316 announcements that involve multiple products, 518 announcements that involve first movers, and 543 announcements that involve original products. 


\section{Results}

In this section, we first report stock price response for the announcing firms and industry rivals. Then, we discuss the results of the crosssectional analysis of the announcement-period abnormal returns of industry rivals.

\section{A. Stock Price Response for the Announcing Firms and Industry Rivals}

Table 2 provides estimates of abnormal returns for the announcement date and the surrounding days. The product announcers experience significantly positive abnormal returns for the day of announcement and the 2-day announcement period (days - 1 to 0 ). For the 2-day announcement period, the product announcers experience an average gain of $0.38 \%$. These results are consistent with previous studies that new product announcement has a positive impact on the announcing firm's value (Woolridge 1988; Chaney et al. 1991; Kelm et al. 1995; Lane and Jacobson 1995; and Chen and Ho 1997).

Table 2 also presents the results for industry rival firms pooled into an equally weighted portfolio that has the same four-digit SIC code. ${ }^{22}$ Industry rivals experience small but significantly negative abnormal returns for the day of announcement and the 2-day announcement period. For the 2-day announcement period, the rivals experience an average loss of $0.12 \%$. The results suggest that, on average, the market substitution effect dominates the market expansion effect.

To explore the question of how much of the market value gains of innovating firms represents "business stealing" from rivals, we calculate the dollar value of gains to announcing firms and the dollar losses experienced by rival firms. Using the firms' market value of equity for the fiscal year preceding the announcement and the 2-day $(-1,0)$ announcement-period abnormal return, we find that, at 1987 prices, the average dollar gain to the announcing firms is $\$ 49.3$ million $^{23}$ and the average total dollar loss experienced by industry rivals corresponding to each new product announcement is $\$ 29.7$ million. At 1995 prices, the corresponding dollar gain to the announcers and the dollar loss experienced by industry rivals are $\$ 66.1$ million and $\$ 39.8$ million, respectively.

22. Previous studies used either the value-weighted or equally weighted methods to form rival portfolios (Slovin et al. 1991; Lang and Stulz 1992; Szewczyk 1992; and others). Lang and Stulz (1992) document little difference between the results obtained by using the equally weighted and value-weighted methods. Our conclusions in this study remain unchanged when the value-weighted method is used.

23. It is interesting to note that the average dollar gain to the announcers in our sample is comparable to that found in Chaney et al. (1991). Chaney et al. report that, based on 3-day announcement-period returns, the average dollar gain to the firms that made new product announcements during the period 1975-84 is \$26.6 million at 1972 prices. When this amount is restated at 1987 prices, the average dollar gain to the announcers in their sample is about $\$ 72$ million based on 3-day announcement returns, which is equivalent to $\$ 48$ million on a 2-day basis. 
TABLE 2 Abnormal Returns Associated with New Product Announcements

\begin{tabular}{|c|c|c|c|c|c|c|}
\hline \multirow[b]{2}{*}{ Event Days } & \multicolumn{3}{|c|}{ Announcing Firms } & \multicolumn{3}{|c|}{ Industry Rivals } \\
\hline & $\begin{array}{c}\text { Average } \\
\text { AR } \\
(\%)\end{array}$ & $\begin{array}{c}\text { Median } \\
\text { AR } \\
(\%)\end{array}$ & Z-Statistic & $\begin{array}{c}\text { Average } \\
\text { AR } \\
(\%)\end{array}$ & $\begin{array}{c}\text { Median } \\
\text { AR } \\
(\%)\end{array}$ & Z-Statistic \\
\hline$[-30,-4]$ & -.19 & -.17 & -.67 & -.03 & -.03 & -.54 \\
\hline-3 & .02 & -.07 & -.14 & -.03 & -.04 & -1.14 \\
\hline-2 & .07 & -.01 & -.69 & -.01 & .00 & .23 \\
\hline-1 & .08 & .03 & 1.52 & -.05 & -.06 & -1.55 \\
\hline 0 & .30 & .18 & 3.72 & -.07 & -.05 & -2.75 \\
\hline$[-1,0]$ & .38 & .21 & 3.70 & -.12 & -.06 & -2.49 \\
\hline+1 & .04 & -.08 & -.03 & -.02 & -.06 & -.69 \\
\hline+2 & -.03 & -.14 & -.43 & -.02 & -.08 & -.94 \\
\hline & -.09 & -.03 & -.33 & -.02 & -.02 & .80 \\
\hline$[+4,+30]$ & -.31 & -.12 & -1.08 & -.07 & -.13 & -1.19 \\
\hline
\end{tabular}

Note.- This table provides estimates of abnormal returns for the announcement date and the surrounding days. We estimate the abnormal return (AR) using the standard market model procedure with parameters estimated for the period 200 days to 60 days before the announcement. We generate abnormal returns for the firm announcing new product introduction and industry rival firms pooled into an equally weighted portfolio. The industries are based on the four-digit SIC code in Compustat. We conduct significance tests using the $Z$-statistic described in Dodd and Warner (1983).

The results suggest that a substantial portion of the dollar gain to the announcers represents "business stealing" from the rival firms.

Table 3 presents the rivals' 2 -day announcement-period average abnormal returns by industry. Out of 60 industries, $39(65 \%)$ have negative average 2-day announcement-period abnormal returns, which is significantly more than one would expect under the null hypothesis of no abnormal returns. Rivals in such technologically based industries as pharmaceuticals preparations (2834), computer and office equipment (3570), electronic and other electric equipment (3600), radio and TV communication equipment (3663), and semiconductors (3674) experience the most-significantly unfavorable share price response. As mentioned by Chaney et al. (1991), firms in these industries require new innovations to stay alive. Therefore, rivals lagging behind in introducing new products in these industries are likely to lose more competitive advantage and experience more significantly negative share price response.

\section{B. Cross-Sectional Analysis}

Table 4 presents cross-sectional analysis of the announcement-period abnormal returns of industry rivals. ${ }^{24}$ All regressions are estimated using weighted least squares, with the weights equal to the inverse of the standard deviation of the market-model residual. This procedure is used

24. Examining individual rival firms, as opposed to rival portfolios, allows us to test the importance of firm-specific variables in explaining the cross-sectional variation in abnormal returns to rivals (as in Song and Walking 2000; and others). 
TABLE 3 Rivals' 2-Day Announcement-Period Average Abnormal Returns for Each Industry in the Sample

\begin{tabular}{|c|c|c|c|}
\hline Industry & $\begin{array}{l}\text { Number of } \\
\text { Firms }\end{array}$ & $\begin{array}{c}\text { CAR } \\
(\%)\end{array}$ & Z-Statistic \\
\hline Food and kindred products $(2000)$ & 7 & .05 & .37 \\
\hline Preserved fruits and vegetables (2030) & 7 & -.10 & -.02 \\
\hline Grain mill products $(2040)$ & 9 & -2.15 & -.19 \\
\hline Sugar and confectionery products $(2060)$ & 7 & 1.31 & 1.68 \\
\hline Beverages (2080) & 8 & .16 & .94 \\
\hline Paper mills (2621) & 16 & .00 & -.01 \\
\hline Misc. converted paper products $(2670)$ & 13 & -.09 & -.25 \\
\hline Newspapers (2711) & 16 & -.10 & -.27 \\
\hline Chemicals and allied products $(2800)$ & 11 & -.21 & -.46 \\
\hline Plastics materials and synthetics $(2820)$ & 2 & 1.01 & 1.60 \\
\hline Plastics materials and resins (2821) & 9 & -.04 & -.02 \\
\hline Pharmaceuticals preparations (2834) & 45 & -.17 & -2.67 \\
\hline Diagnostic substances (2835) & 12 & -.17 & -.11 \\
\hline Biological products not diagnostic (2836) & 4 & -.67 & -.20 \\
\hline Soap, cleaners, and toilet goods (2840) & 5 & -.17 & -.29 \\
\hline Toilet preparations $(2844)$ & 14 & -.22 & -.17 \\
\hline Petroleum refining (2911) & 38 & .08 & 1.73 \\
\hline Tires and inner tubes (3011) & 3 & 1.07 & .85 \\
\hline Glass/glassware (3220) & 1 & 2.67 & 1.14 \\
\hline Misc. nonmetallic mineral products $(3290)$ & 1 & -.12 & -.16 \\
\hline Cutlery, handtools, and hardware (3420) & 9 & -.16 & -.31 \\
\hline Engines and turbines $(3510)$ & 9 & .98 & 1.61 \\
\hline Farm machinery and equipment (3523) & 3 & .43 & .56 \\
\hline Metalworking machinery (3540) & 7 & -.19 & -.02 \\
\hline Special industry machinery (3559) & 6 & -1.12 & -1.18 \\
\hline General industry machinery (3569) & 2 & -1.07 & -.72 \\
\hline Computer and office equipment ( 3570$)$ & 7 & -.19 & -2.31 \\
\hline Electronic computers $(3571)$ & 11 & -.10 & -.54 \\
\hline Computer storage devices (3572) & 8 & .19 & .09 \\
\hline Computer terminals $(3575)$ & 4 & .49 & .15 \\
\hline Computers - others (3576) & 3 & 1.33 & .68 \\
\hline Computer peripherals $(3577)$ & 7 & -1.12 & -.89 \\
\hline Calculating/accounting equipment (3578) & 3 & -1.42 & -1.40 \\
\hline Office machines $(3579)$ & 2 & -.18 & -.12 \\
\hline Electronic/other electric equipment (3600) & 4 & -.45 & -2.17 \\
\hline Motors and generators $(3621)$ & 7 & .71 & .55 \\
\hline Household appliances (3630) & 3 & .58 & .35 \\
\hline Electric lighting/wiring equipment (3640) & 12 & -.17 & -.80 \\
\hline Household audio/video equipment (3651) & 7 & -.27 & -.82 \\
\hline Telephone and telegraph apparatus (3661) & 14 & -.08 & -.09 \\
\hline Radio/TV communication equipment (3663) & 12 & -.47 & -2.22 \\
\hline Semiconductors $(3674)$ & 20 & -.45 & -1.81 \\
\hline Misc. electrical equipment/supplies (3690) & 7 & 1.68 & 1.44 \\
\hline Motor vehicles and car bodies (3711) & 11 & -.19 & -1.17 \\
\hline Motor vehicle parts (3714) & 28 & -.30 & -.21 \\
\hline Aircraft (3721) & 4 & -.99 & -1.55 \\
\hline Aircraft engines and parts (3724) & 4 & -.52 & -.33 \\
\hline Guided missiles (3760) & 4 & 1.44 & 1.66 \\
\hline Instruments and related products $(3825)$ & 11 & -.49 & -1.36 \\
\hline Surgical and medical instruments (3841) & 11 & -.10 & -.19 \\
\hline Surgical appliance and supplies (3842) & 5 & 2.22 & 1.09 \\
\hline X-ray apparatus and tubes (3844) & 2 & -.24 & -.04 \\
\hline Electromedical equipment (3845) & 9 & -.20 & -.15 \\
\hline Ophthalmic goods (3851) & 3 & -.34 & -.13 \\
\hline
\end{tabular}


TABLE 3

(Continued)

\begin{tabular}{lcrr}
\hline Industry & $\begin{array}{c}\text { Number of } \\
\text { Firms }\end{array}$ & $\begin{array}{c}\text { CAR } \\
(\%)\end{array}$ & Z-Statistic \\
\hline Photographic equipment/supplies (3861) & 6 & -.08 & -.52 \\
Dolls and stuffed toys (3942) & 1 & 1.20 & 1.18 \\
Games/toys/children's vehicles (3944) & 7 & .03 & -.07 \\
Telephone communication not radio (4813) & 35 & .01 & .47 \\
Hotels and motels (7011) & 11 & -.04 & -.04 \\
Motion pictures (7819) & 2 & -.27 & -.09 \\
\hline
\end{tabular}

NoTE.- This table presents the 2-day announcement-period average abnormal returns, CAR, for industry rivals classified by industry. The industries are based on the four-digit SIC code in Compustat. We conduct significance tests using the Z-statistic described in Dodd and Warner (1983).

to obtain efficient estimates, since the variances of the market-model residuals vary across firms (see Lang et al. 1991; and others). ${ }^{25}$ We present the results of eight regression models. The first four models exclude industry dummies and the last four include them. ${ }^{26}$

Model 1 includes only ACAR, the 2-day announcement-period abnormal returns of the announcers. We find a significantly negative relation between rivals' share price effect and ACAR. The result shows that, on average, the market substitution effect dominates the market expansion effect. The finding also supports the notion that the extent of the announcement effects on rivals is significantly influenced by the extent to which the new product announcement is anticipated. A large effect on the announcer suggests a significant "surprise" value associated with the announcement, which would elicit a more negative wealth effect on industry rivals.

Model 2 includes ACAR, announcement frequency (FREQ), and all variables relating to the industry characteristics, the rivals' firm characteristics, and the product announcement type. The results show that the coefficient of ACAR remains significantly negative, after including other potentially important variables in the regression.

We find in model 2 that rivals' share price response is significantly negatively related to FREQ. Chaney et al. (1991) suggest that the degree of surprise is greater when announcements are made by firms that have no history of making frequent product announcements. The wealth effect on industry rivals should be more negative when there is a greater element of surprise. Therefore, the relation between FREQ and rivals' wealth effect should be positive. However, we find the opposite sign. Our finding could be explained by the evidence in Kelm et al. (1995) and Chen et al. (2002) that the more-frequent new product announcers experience higher abnormal returns than the less-frequent new product

25. Ordinary least squares yield similar results.

26. Baseline comparison is to the industry of chemicals and allied products (2800). 
TABLE 4 Weighted Least Squares Analysis of Announcement-Period Abnormal Returns of Rivals

\begin{tabular}{|c|c|c|c|c|c|c|c|c|}
\hline \multirow[b]{2}{*}{ Independent Variables } & \multicolumn{8}{|c|}{ Models } \\
\hline & (1) & (2) & (3) & (4) & (5) & (6) & (7) & (8) \\
\hline INTERCEPT & $\begin{array}{c}-.02 \\
(-1.03)\end{array}$ & $\begin{array}{l}-.09 \\
(-.60)\end{array}$ & $\begin{array}{l}-.12 \\
(-.79)\end{array}$ & $\begin{array}{c}-.60 \\
(-1.42)\end{array}$ & $\begin{array}{c}.17 \\
(1.24)\end{array}$ & $\begin{array}{l}.28 \\
(.17)\end{array}$ & $\begin{array}{l}.18 \\
(.11)\end{array}$ & $\begin{array}{l}-.27 \\
(-.16)\end{array}$ \\
\hline \multicolumn{9}{|l|}{ Degree of "surprise" } \\
\hline ACAR & $\begin{array}{c}-.04 \\
(-3.08)^{* * *}\end{array}$ & $\begin{array}{c}-.03 \\
(-2.46)^{* *}\end{array}$ & $\begin{array}{c}-.03 \\
(-2.47)^{* *}\end{array}$ & $\begin{array}{c}-.03 \\
(-2.69) * * *\end{array}$ & $\begin{array}{c}-.03 \\
(-2.22)^{* *}\end{array}$ & $\begin{array}{c}-.02 \\
(-1.70) *\end{array}$ & $\begin{array}{c}-.02 \\
(-1.71)^{*}\end{array}$ & $\begin{array}{c}-.03 \\
(-1.98) * *\end{array}$ \\
\hline FREQ & & $\begin{array}{c}-.01 \\
(-1.67)^{*}\end{array}$ & $\begin{array}{c}-.01 \\
(-1.81)^{*}\end{array}$ & $\begin{array}{c}-.01 \\
(-1.89)^{*}\end{array}$ & & $\begin{array}{c}-.01 \\
(-3.65)^{* * *}\end{array}$ & $\begin{array}{c}-.01 \\
(-3.62) * * *\end{array}$ & $\begin{array}{c}-.01 \\
(-3.82)^{* * *}\end{array}$ \\
\hline \multicolumn{9}{|l|}{ Industry characteristics: } \\
\hline $\mathrm{HI}$ & & $\begin{array}{l}.02 \\
(.11)\end{array}$ & $\begin{array}{c}.24 \\
(1.21)\end{array}$ & $\begin{array}{c}.27 \\
(1.35)\end{array}$ & & $\begin{array}{l}.56 \\
(.69)\end{array}$ & $\begin{array}{c}1.01 \\
(1.22)\end{array}$ & $\begin{array}{c}.96 \\
(1.14)\end{array}$ \\
\hline HIGH TECH & & $\begin{array}{c}-.15 \\
(-2.63) * * *\end{array}$ & $\begin{array}{c}-.14 \\
(-2.39) * *\end{array}$ & $\begin{array}{c}-.15 \\
(-2.58) * * *\end{array}$ & & $\begin{array}{c}-.51 \\
(-.31)\end{array}$ & $\begin{array}{c}-.42 \\
(-.26)\end{array}$ & $\begin{array}{c}-.45 \\
(-.28)\end{array}$ \\
\hline Rival's firm characteristics & & & & & & & & \\
\hline SIZE & & $\begin{array}{c}.02 \\
(2.13)^{* *}\end{array}$ & $\begin{array}{c}.02 \\
(2.07)^{* *}\end{array}$ & $\begin{array}{c}.02 \\
(2.11)^{* *}\end{array}$ & & $\begin{array}{c}.02 \\
(1.55)\end{array}$ & $\begin{array}{c}.02 \\
(1.62)^{*}\end{array}$ & $\begin{array}{c}.02 \\
(1.67)^{*}\end{array}$ \\
\hline Q & & $\begin{array}{c}-.17 \\
(-2.63)^{* * *}\end{array}$ & $\begin{array}{c}-.17 \\
(-2.61)^{* * *}\end{array}$ & $\begin{array}{c}-.17 \\
(-2.66)^{* * *}\end{array}$ & & $\begin{array}{c}-.17 \\
(-2.70)^{* * *}\end{array}$ & $\begin{array}{c}-.17 \\
(-2.64)^{* * *}\end{array}$ & $\begin{array}{c}-.17 \\
(-2.67)^{* * *}\end{array}$ \\
\hline FCF & & $\begin{array}{l}-.16 \\
(-.39)\end{array}$ & $\begin{array}{l}-.24 \\
(-.59)\end{array}$ & $\begin{array}{l}-.25 \\
(-.61)\end{array}$ & & $\begin{array}{l}-.37 \\
(-.86)\end{array}$ & $\begin{array}{c}-.47 \\
(-1.07)\end{array}$ & $\begin{array}{c}-.46 \\
(-1.06)\end{array}$ \\
\hline RDI & & $\begin{array}{c}-.79 \\
(-2.74)^{* * *}\end{array}$ & $\begin{array}{c}-.79 \\
(-2.71)^{* * *}\end{array}$ & $\begin{array}{c}-.79 \\
(-2.74)^{* * *}\end{array}$ & & $\begin{array}{c}-.39 \\
(-1.23)\end{array}$ & $\begin{array}{c}-.43 \\
(-1.36)\end{array}$ & $\begin{array}{c}-.42 \\
(-1.33)\end{array}$ \\
\hline
\end{tabular}


Models

\begin{tabular}{|c|c|c|c|c|c|c|c|c|}
\hline \multirow[b]{2}{*}{ Independent Variables } & & & & & & & & \\
\hline & (1) & (2) & (3) & (4) & (5) & (6) & (7) & (8) \\
\hline \multirow[t]{2}{*}{ DEBT RATIO } & & -.31 & -.11 & -.14 & & -.46 & -.19 & -.19 \\
\hline & & $(-2.25)^{* *}$ & $(-.72)$ & $(-.88)$ & & $(-3.09) * * *$ & $(-.99)$ & $(-.99)$ \\
\hline \multirow[t]{2}{*}{ DEBT RATIO $\times$ HIGH HI } & & & -.40 & -.38 & & & -.52 & -.52 \\
\hline & & & $(-2.57)^{* * *}$ & $(-2.39)^{* *}$ & & & $(-2.48)^{* *}$ & $(-2.49)^{* *}$ \\
\hline \multicolumn{9}{|l|}{ Product announcement type: } \\
\hline \multirow[t]{2}{*}{ MULTIPLE } & & -.07 & -.07 & 1.05 & & -.09 & -.10 & 1.16 \\
\hline & & $(-1.46)$ & $(-1.47)$ & $(.42)$ & & $(-2.01)^{* *}$ & $(-2.12)^{* *}$ & $(.46)$ \\
\hline \multirow{2}{*}{ TIME } & & .05 & .05 & .28 & & .07 & .07 & .27 \\
\hline & & $(.99)$ & $(.95)$ & $(.86)$ & & $(1.39)$ & $(1.29)$ & $(.81)$ \\
\hline \multirow[t]{2}{*}{ NEW } & & .12 & .12 & .34 & & .15 & .15 & .36 \\
\hline & & $(2.71)^{* * *}$ & $(2.82)^{* * *}$ & $(2.17)^{* *}$ & & $(3.28)^{* * *}$ & $(3.28)^{* * *}$ & $(2.25)^{* *}$ \\
\hline \multirow[t]{2}{*}{ MULTIPLE $\times$ TIME } & & & & -.38 & & & & -.46 \\
\hline & & & & $(-.15)$ & & & & $(-.18)$ \\
\hline \multirow{2}{*}{ MULTIPLE $\times$ NEW } & & & & -.50 & & & & -.54 \\
\hline & & & & $(-.59)$ & & & & $(-.63)$ \\
\hline \multirow[t]{2}{*}{ TIME $\times$ NEW } & & & & -.10 & & & & -.09 \\
\hline & & & & $(-.86)$ & & & & $(-.76)$ \\
\hline \multirow[t]{2}{*}{ MULTIPLE $\times$ TIME $\times$ NEW } & & & & .19 & & & & .20 \\
\hline & & & & $(.22)$ & & & & $(.24)$ \\
\hline Industry dummies & No & No & No & No & Yes & Yes & Yes & Yes \\
\hline$N$ & 5,865 & 5,865 & 5,865 & 5,865 & 5,865 & 5,865 & 5,865 & 5,865 \\
\hline Adjusted $R^{2}$ & $.16 \%$ & $1.00 \%$ & $1.10 \%$ & $1.22 \%$ & $1.20 \%$ & $2.04 \%$ & $2.13 \%$ & $2.27 \%$ \\
\hline$F$-value & $9.51 * * *$ & $5.95 * * *$ & $6.00 * * *$ & $5.25 * * *$ & $2.32 * * *$ & $2.88 * * *$ & $2.93 * * *$ & $2.95 * * *$ \\
\hline
\end{tabular}

NoTE.- The dependent variable is the 2-day announcement-period abnormal returns of industry rivals. ACAR is the 2-day announcement-period abnormal returns of announcing firms. We estimate the announcement-period abnormal returns using the standard market model procedure with parameters estimated for the period 200 days to 60 days before the announcement. FREQ is the number of new product announcements made by an announcing firm over the sample period. The Herfindahl index (HI) is the sum of the squared fraction of industry sales by all firms in the industry for the fiscal year prior to the announcement. HIGH TECH equals 1 if the rival firms are in a high-technology industry and zero otherwise. Rival's firm size (SIZE) equals the logarithm of book value of total assets for the fiscal year preceding the announcement. The dummy variable for $q$ (Q) is equal to 1 if the rival firm's $q$ is greater than 1 and zero otherwise. We estimate rival firm's $q$ as the average ratio of the market value of the assets to the book value of the firm's assets for the 3 fiscal years before the announcement, where the market value of assets equals the book value of assets minus the book value of common equity plus the market value of common equity. We define rival firm's free cash flow (FCF) as operating income before depreciation minus interest expense, taxes, preferred dividends, and common dividends, divided by book value of total assets, for the fiscal year preceding the announcement. The rival firm's R\&D intensity (RDI) equals R\&D per dollar of sales for the fiscal year prior to the announcement. The rival firm's debt ratio (DEBT RATIO) equals the book value of total debt divided by the book value of total assets, for the fiscal year preceding the announcement. DEBT RATIO $\times$ HIGH HI is an interaction term, where HIGH HI equals 1 if the Herfindahl index is greater than the sample median and zero otherwise. MULTIPLE equals 1 for multiple-product announcements and zero for single-product announcements. TIME equals 1 if the announcing firm is the first mover and zero otherwise. NEW equals 1 if the product is an original product and zero if it is an update. The industries are based on the four-digit SIC code in Compustat. Baseline comparison is to the industry of chemicals and allied products (2800). The $t$-statistics are in parentheses; ***, $* *$, and $*$ represent $1 \%, 5 \%$, and $10 \%$ significance levels, respectively. 
announcers. Their evidence is contrary to the finding in Chaney et al. (1991). Chen et al. (2002) argue that the higher abnormal returns experienced by frequent new product announcers might suggest that these firms are able to capitalize on follow-on investment projects and generate future investment opportunities, ${ }^{27}$ which could erode the competitive position of the rival firms. Thus, new product announcements made by frequent announcers could elicit a more-negative wealth effect on the rivals. The significantly negative relation between rivals' share price response and FREQ that we find is consistent with this explanation.

Model 2 shows that the coefficient of $\mathrm{HI}$ is not significant, although the positive sign is consistent with our prediction that rivals in industries with lower value of the Herfindahl index (i.e., more competitive industries) experience a more unfavorable wealth effect. We find that the coefficient of the HIGH TECH dummy is significantly negative. This finding is consistent with the hypothesis that the wealth effect of new product introductions on industry rivals in high-technology industries is more unfavorable than that on rivals in low-technology industries. Thus, laggards in more technologically based industries are "punished" more by the capital market than those in less technologically based industries.

Model 2 also shows that rivals' share price response is significantly positively related to their firm size (SIZE). Small firms, which need product innovation to survive in the market, are more vulnerable to competitors' challenges and, hence, have poorer share price response. Furthermore, information asymmetry is more severe for small firms, and any expected negative change in firm value induced by public announcements of new product introductions should be more pronounced for small rival firms.

As for the other firm-level variables, we find that rivals' share price response is significantly negatively related to their Tobin's q (Q), R\&D intensity (RDI), and leverage (DEBT RATIO) but not significantly related to their free cash flow (FCF). Firms with better investment opportunities are likely to have worthwhile investments, better investment decisions, and more growth options; and firms with high R\&D intensity are expected to have greater technology capability and opportunities for product innovation. If they do not perform up to the market's expectation, as in the case of lagging behind in product innovation, the market is more disappointed in these firms. Our results are consistent with this

27. Kasanen (1993) suggests that firms can create value by "spawning" investment opportunities and a collection of projects linked together through cross-spawning can be worth more than the sum of the individual projects. Smit and Ankum (1993) also suggest that an investment strategy can encompass a sequence of projects, of which several may yield a low return when considered in isolation but are valuable in generating options to invest in followon projects. 
prediction. Our finding on leverage is consistent with the notion that a firm's leverage increases its vulnerability in product market competition. We find that, although free cash flow is not statistically significant at conventional levels, it has a negative sign, which is consistent with the theoretical prediction.

Of the three variables related to the product announcement type, only product newness (NEW) is significantly positively related to rivals' share price response. The other two variables, single- or multiple-product announcement (MULTIPLE) and entry timing (TIME), are not significant. Our results are consistent with the notion that the market expansion effect of a new product introduction is more likely to happen when the products introduced are original. Industry rivals benefit from this market growth and, hence, experience a favorable stock price response. On the other hand, when the products introduced are simply updates of existing products, an accelerated market growth is less likely to occur; hence, industry rivals experience a less-favorable stock price response.

In model 3, we include all the variables in model 2 and an interaction term, DEBT RATIO $\times$ HIGH HI. Our results show that the interaction term between leverage and high industry concentration is significantly negatively related to the rivals' share price response, but the coefficient of DEBT RATIO is no longer significant. This finding is consistent with our prediction that highly leveraged firms in concentrated industries are more vulnerable in product market competition. Our results also suggest that leverage is less important in explaining the wealth effect of new product introductions on rivals in less concentrated industries.

In model 4, we examine the role of four interaction termsMULTIPLE $\times$ TIME, MULTIPLE $\times$ NEW, TIME $\times$ NEW, and MULTIPLE $\times$ TIME $\times$ NEW-in addition to the variables in model 3 . Chaney et al. (1991) find that firms that introduce multiple original products experience the largest wealth impact, and those that introduce single-product updates show the smallest impact. Therefore, the results in Chaney et al. (1991) suggest that rivals' share price response might be influenced by the interaction effect among MULTIPLE, TIME, and NEW. However, we find that these interaction terms do not appear important in explaining the rivals' share price response. In this model, the results on the other variables are unchanged.

Models 5 to 8 repeat models 1 to 4 by including industry dummies. The results are similar to those without industry dummies except for the followings. The HIGH TECH dummy and R\&D intensity are no longer statistically significant at conventional levels once industry dummies are included, although their signs are still negative. ${ }^{28}$ Our results show that

28. We also reran models 6 to 8 without the two industry-level variables, HI and HIGH $\mathrm{TECH}$, and the results of the other variables in the models remain unchanged. 
the effects of the HIGH TECH dummy and R\&D intensity are subsumed in the industry dummies. We also find that the results on SIZE are weaker, but our conclusion on this variable remains unchanged. Finally, we find that the coefficient of MULTIPLE is significantly negative in models 6 and 7 but not significant in model 8 . We recognize that the mixed results on MULTIPLE and the insignificance of variables such as TIME might be due to the noisy estimates for the proxy variables.

\section{Conclusion}

This paper examines the wealth impact of new product introductions on industry rivals. The market expansion effect predicts that industry rivals should experience a positive wealth effect, and the market substitution effect predicts that they should experience a negative wealth effect. We show that, on average, rival firms experience a small but significantly negative share price response. The finding suggests that, for our sample as a whole, the market substitution effect dominates the market expansion effect. Our results show that a significant portion of the wealth gain to the announcers represents business stealing from the industry rivals.

The main contribution of our paper comes in understanding the cross-sectional variation of rivals' share price response to new product announcements. We show that the wealth effects on the announcers and the industry rivals are significantly negatively related. Therefore, if an announcement is less anticipated, there should be a more-positive wealth effect on the announcers and a more-negative impact on rivals. We also find that rivals' share price response is more unfavorable when frequent announcers introduce new products.

We further show that the wealth effect on rivals varies from industry to industry. Rivals in high-technology industries experience a more unfavorable share price response. However, this result is not significant once we include individual industry dummies in our regressions.

We also relate the rivals' share price response to their firm characteristics. We find that the negative share price effect on industry rivals is more pronounced for smaller rival firms and those rival firms that have better investment opportunities. We also show that rivals with higher levels of debt experience a more-unfavorable wealth effect. The vulnerability of leveraged rival firms is more severe if they operate in concentrated industries. We find that the wealth effect of industry rivals is significantly negatively related to their R\&D intensity. However, this result is subsumed once we include individual industry dummies in our analysis.

Our results also show that product newness is the only variable relating to product announcement type that is consistently significantly related to rivals' share price response. We find that the wealth effect on rival firms is more favorable when the announcing firms introduce original products. 


\section{References}

Acs, Z., and D. Audretsch. 1988. Innovation in large and small firms: An empirical analysis. American Economic Review 78:678-90.

Aharony, J., and I. Swary. 1983. Contagion effects of bank failures: Evidence from capital markets. Journal of Business 56:305-22.

Akhigbe, A., and J. Madura. 1996. Intra-industry effects of voluntary corporate liquidations. Journal of Business Finance and Accounting 23:915-930.

Ashok, T. 1994. A study of product and financial market interactions. Ph.D. thesis, Purdue University.

Atiase, R. 1985. Predisclosure information, firm capitalization, and security price behavior around earnings announcements. Journal of Accounting Research 23:21-36.

Baginski, S. 1987. Intraindustry information transfers associated with management forecasts of earnings. Journal of Accounting Research 25:196-219.

Barclay, M., and C. Smith. 1995. The maturity structure of corporate debt. Journal of Finance 50:609-31.

Bernardo, A., and B. Chowdhry. 2002. Resources, real options, and corporate strategy. Journal of Financial Economics 63:211-34.

Bolton, P., and D. Scharfstein. 1990. A theory of predation based on agency problems in financial contracting. American Economic Review 80:93-106.

Booz, Allen, and Hamilton, Inc. 1982. New products management for the 1980s. New York: Booz, Allen and Hamilton, Inc.

Brander, J., and T. Lewis. 1986. Oligopoly and financial structure. American Economic Review 76:956-70.

Chan, L., J. Lakonishok, and T. Sougiannis, T. 2001. The stock market valuation of research and development expenditures. Journal of Finance 56:2431-56.

Chan, S., J. Martin, and J. Kensinger. 1990. Corporate research and development expenditures and share value. Journal of Financial Economics 26:255-76.

Chaney, P., T. Devinney, and R. Winer. 1991. The impact of new product introductions on the market value of firms. Journal of Business 64:573-610.

Chen, S., and K. Ho. 1997. Market response to product-strategy and capital-expenditure announcements in Singapore: Investment opportunities and free cash flow. Financial Management 26:82-88.

Chen, S., K. Ho, K. Ik, and C. Lee. 2002. How does strategic competition affect firm values? A study of new product announcements. Financial Management 31:67-84.

Chevalier, J. 1995. Capital structure and product-market competition: Empirical evidence from the supermarket industry. American Economic Review 85:415-35.

Chung, K., and S. Pruitt. 1994. Simple approximation of Tobin's q. Financial Management 23:70-74.

Chung, K., P. Wright, and C. Charoenwong. 1998. Investment opportunities and market reaction to capital expenditure decisions. Journal of Banking and Finance 22:41-60.

Deng, Z., B. Lev, and F. Narin. 1999. Science and technology as predictors of stock performance. Financial Analysts Journal 55:20-32.

Denis, D. 1994. Investment opportunities and the market reaction to equity offerings. Journal of Financial and Quantitative Analysis 29:159-77.

Dodd, P., and J. Warner. 1983. On corporate governance: A study of proxy contexts. Journal of Financial Economics 11:401-38.

Eckbo, B. 1983. Horizontal mergers, collusion, and stockholder wealth. Journal of Financial Economics 11:241-73.

Eckel, C., D. Eckel, and V. Singal. 1997. Privatization and efficiency: Industry effects of the sale of British Airways. Journal of Financial Economics 43:275-98.

Fazzari, S., G. Hubbard, and B. Petersen. 1988. Finance constraints and corporate investment. Brookings Papers on Economic Activity 1:141-95.

Firth, M. 1996. Dividend changes, abnormal returns, and intra-industry firm valuations. Journal of Financial and Quantitative Analysis 31:189-211.

Firth, R., and V. Narayanan. 1996. New product strategies of large, dominant product manufacturing firms: An exploratory analysis. Journal of Product Innovation Management 13:334-47. 
Foster, G. 1981. Intra-industry information transfers associated with earnings releases. Journal of Accounting and Economics 3:201-32.

Gertner, R., R. Gibbons, and D. Scharfstein. 1988. Simultaneous signaling to the capital and product markets. RAND Journal of Economics 19:173-90.

Guenther, D., and A. Rosman. 1994. Difference between Compustat and CRSP SIC codes and related effects on research. Journal of Accounting and Economics 18:115-28.

Han, J., J. Wild, and K. Ramesh. 1989. Managers' earnings forecasts and intra-industry transfers. Journal of Accounting and Economics 11:3-33.

Hendricks, K., and V. Singhal. 1997. Delays in new product introductions and the market value of the firm: The consequences of being late to the market. Management Science 43:422-36.

Hertzel, M. 1991. The effects of stock repurchases on rival firms. Journal of Finance 46:707-16.

Holderness, C., R. Kroszner, and D. Sheehan. 1999. Were the good old days that good? Changes in managerial stock ownership since the Great Depression. Journal of Finance $54: 435-69$.

Hoshi, T., A. Kashyap, and D. Scharfstein. 1991. Corporate structure, liquidity, and investment: Evidence from Japanese panel data. Quarterly Journal of Economics 106:33-60.

Howe, K., J. He, and G. Kao. 1992. One-time cash flow announcements and free cash-flow theory: Share repurchases and special dividends. Journal of Finance 47:1963-75.

Howton, S., S. Howton, and S. Perfect. 1998. The market reaction to straight debt issues: The effects of free cash flow. Journal of Financial Research 21:219-28.

Jensen, M. 1986. Agency costs of free cash flow, corporate finance, and takeovers. American Economic Review 76:323-29.

Jovanovic, B., and G. MacDonald. 1994. The life cycle of a competitive industry. Journal of Political Economy 102:322-47.

Kahle, K., and R. Walkling. 1996. The impact of industry classifications on financial research. Journal of Financial and Quantitative Analysis 31:309-35.

Kang, J., and R. Stulz. 1996. How different is Japanese corporate finance? An investigation of the information content of new security issues. Review of Financial Studies 9:109-39.

Kasanen, E. 1993. Creating value by spawning investment opportunities. Financial Management 22:251-58.

Kelm, K., V. Narayanan, and G. Pinches. 1995. Shareholder value creation during R\&D innovation and commercialization stages. Academy of Management Journal 38:770-86.

Kleinschmidt, E., and R. Cooper. 1991. The impact of product innovativeness on performance. Journal of Product Innovation Management 8:240-51.

Klemperer, P., and A. Padilla. 1997. Do firms' product lines include too many varieties? RAND Journal of Economics 28:472-88.

Kovenock, D., and G. Phillips. 1995. Capital structure and product-market rivalry: How do we reconcile theory and evidence? American Economic Review 85:403-8.

1997. Capital structure and product market behavior: An examination of plant exit and investment decisions. Review of Financial Studies 10:767-803.

Lane, V., and R. Jacobson. 1995. Stock market reactions to brand extension announcements: The effects of brand attitude and familiarity. Journal of Marketing 59:63-77.

Lang, L., E. Ofek, and R. Stulz. 1996. Leverage, investment, and firm growth. Journal of Financial Economics 40:3-29.

Lang, L., and R. Stulz. 1992. Contagion and competitive intra-industry effects of bankruptcy announcements. Journal of Financial Economics 32:45-60.

Lang, L., R. Stulz, and R. Walkling. 1989. Managerial performance, Tobin's $q$, and the gains from successful takeovers. Journal of Financial Economics 24:315-35.

. 1991. A test of the free cash flow hypothesis: The case of bidder returns. Journal of Financial Economics 29:315-35.

Lee, H. 1995. Shareholder wealth effects of new product rivalry: First movers, second movers, and laggards. Ph.D. thesis, University of Maryland.

Lehn, K., and A. Poulsen. 1989. Free cash flow and stockholder gains in going private transactions. Journal of Finance 44:771-87.

Mahajan, V., S. Sharma, and R. Buzzell. 1993. Assessing the impact of competitive entry on market expansion and incumbent sales. Journal of Marketing 57:39-52. 
Maksimovic, V. 1998. Capital structure in repeated oligopolies. RAND Journal of Economics 19:389-407.

Mankiw, N., and M. Whinston. 1986. Free entry and social efficiency. RAND Journal of Economics 17:48-58.

Maurer, B. 1999. Innovation and investment under financial constraints and product market competition. International Journal of Industrial Organization 17:455-76.

Mauri, J., and M. Michaels. 1998. Firm and industry effects within strategic management: An empirical examination. Strategic Management Journal 19:211-19.

Meyer, M., and E. Roberts. 1986. New product strategy in small technology-based firms: A pilot study. Management Science 32:806-21.

Mueller, D. 1997. First-mover advantages and path dependence. International Journal of Industrial Organization 15:827-50.

Myers, S. 1977. Determinants of corporate borrowing. Journal of Financial Economics $5: 147-75$.

Opler, T., and S. Titman. 1994. Financial distress and corporate performance. Journal of Finance 49:1015-40.

Phillips, G. 1995. Increased debt and industry product markets: An empirical analysis. Journal of Financial Economics 37:189-238.

Poitevin, M. 1989. Financial signaling and the "deep-pocket" argument. RAND Journal of Economics 20:26-40.

Saloner, G., A. Shepard, and J. Podolny. 2001. Strategic management. New York: John Wiley \& Sons.

Scherer, F., and D. Ross. 1990. Industrial market structure and economic performance. Boston: Houghton Mifflin.

Slovin, M., M. Sushka, and Y. Bendeck. 1991. The intra-industry effects of going-private transactions. Journal of Finance 46:1537-50.

Slovin, M., M. Sushka, and J. Polonchek. 1992. Informational externalities of seasoned equity issues. Journal of Financial Economics 32:87-101.

Smit, H., and L. Ankum. 1993. A real options and game-theoretic approach to corporate investment strategy under competition. Financial Management 22:241-50.

Song, M., and R. Walkling. 2000. Abnormal returns to rivals of acquisition targets: A test of the "acquisition probability hypothesis." Journal of Financial Economics 55:143-72.

Stillman, R. 1983. Examining antitrust policy towards horizontal mergers. Journal of Financial Economics 11:225-40.

Stulz, R. 1990. Managerial discretion and financing policies. Journal of Financial Economics 26:3-27.

Szewczyk, S. 1992. The intra-industry transfer of information inferred from announcements of corporate security offerings. Journal of Finance 47:1935-45.

Trigeorgis, L. 1996. Real options: Managerial flexibility and strategy in resource allocation. Cambridge, MA: MIT Press.

Woolridge, J. 1988. Competitive decline and corporate restructuring: Is a myopic stock market to blame? Journal of Applied Corporate Finance 1:26-36.

Zingales, L. 1998. Survival of the fittest or the fattest? Exit and financing in the trucking industry. Journal of Finance 53:905-38. 